\title{
Contrasting Subcellular Localization of the Kv1.2 K+ Channel Subunit in Different Neurons of Rat Brain
}

\author{
Morgan Sheng, Meei-Ling Tsaur, Yuh Nung Jan, and Lily Yeh Jan \\ Howard Hughes Medical Institute and Departments of Physiology and Biochemistry, University of California, San \\ Francisco, California 94143-0724
}

In the nervous system, a wide diversity of $K^{+}$channels are formed by the oligomeric assembly of subunits encoded by a large number of $\mathrm{K}+$ channel genes. The physiological functions of a specific $\mathrm{K}^{+}$channel subunit in vivo will be dictated in part by its subcellular location within neurons. We have used a combined in situ hybridization and immunocytochemical approach to determine the subcellular distribution of Kv1.2, a member of the Shaker subfamily of $\mathrm{K}^{+}$channel genes. In contrast to other characterized $K^{+}$channel subunits, Kv1.2 protein shows a complex differential subcellular distribution in neurons of rat brain. In some of these neurons (e.g., hippocampal and cortical pyramidal cells, and Purkinje cells), Kv1.2 is concentrated in dendrites, while in others (e.g., cerebellar basket cells), Kv1.2 is predominantly, if not exclusively, localized to nerve terminals. Furthermore, Kv1.2 immunoreactivity was also detected in certain axon tracts. We hypothesize that the differential sorting of Kv 1.2 could result from association of Kv1.2 with varying heterologous $\mathrm{K}^{+}$channel subunits in different cell types, with the implication that Kv1.2 may participate in distinct heteromultimeric $\mathrm{K}+$ channels in different subcellular domains. The findings suggest that Kv1.2-containing $K+$ channels may play diverse functional roles in several neuronal compartments, regulating presynaptic or postsynaptic membrane excitability, depending on the neuronal cell type.

[Key words: potassium channels, rat brain, hippocampus, cerebellum, axons, dendrites, nerve terminals, heteromultimer, subcellular sorting]

$\mathrm{K}^{+}$channels comprise the most diverse class of voltage-gated ion channels. Being key determinants of membrane excitability, they regulate many aspects of neuronal physiology, such as resting membrane potential, firing rate, and synaptic transmission (Hille, 1991). This wide range of functions is likely to be performed by a variety of specialized $\mathrm{K}^{+}$channel subtypes encoded by distinct (or distinct combinations of) $\mathrm{K}^{+}$channel genes. Consistent with this idea, a large number of genes for voltage-gated $\mathrm{K}^{+}$channel subunits have been isolated (reviewed in Jan and Jan, 1990; Salkoff et al., 1992) that encode for $\mathrm{K}^{+}$conductances with different kinetic and pharmacological properties when ex-

\footnotetext{
Received June 22, 1993; revised Sept. 17, 1993; accepted Oct. 14, 1993.

We thank Leslie Roldan for excellent technical assistance, D. McKinnon for $\mathrm{Kv} 1.2 \mathrm{cDNA}$, and Larry Ackerman and William Walantus for photography. This work was supported by the Silvio Conte Center Grant from the National Institute of Mental Health. Y.N.J. and L.Y.J. are Hughes Investigators; M.S. was supported by the National Multiple Sclerosis Society, and is now a recipient of a Howard Hughes Postdoctoral Fellowship for Physicians.

Correspondence should be addressed to Lily Yeh Jan at the above address.

Copyright (C) 1994 Society for Neuroscience $0270-6474 / 94 / 142408-10 \$ 05.00 / 0$
}

pressed in Xenopus oocytes. Moreover, these subunits can assemble into heteromultimeric channcls with novel characteristics, thus generating a further level of diversity (Christie et al., 1990; Isacoff et al., 1990; McCormack et al., 1990; Ruppersberg et al., 1990).

Despite rapid progress in the electrophysiological characterization of cloned $\mathrm{K}^{+}$channels, however, little is known about the specific roles played by the various $\mathrm{K}^{+}$channel gene products in vivo. This problem is compounded by the considerable overlap in functional properties between known $\mathrm{K}^{+}$channel genes, at least when assayed in heterologous expression systems. Toward understanding the neurobiological functions of a specific $\mathrm{K}^{+}$channel subunit, important steps include (1) mapping the expression pattern of its mRNA in the nervous system, (2) defining the localization of the subunit protein at the subcellular level, (3) determining the molecular composition of the $\mathrm{K}^{+}$ channel complex of which it is a component, and (4) correlating the expression of the $\mathrm{K}^{+}$channel subunit with the specific cellular conductances to which it contributes.

Such approaches have shed light on the functions of two rat $\mathrm{K}^{+}$channel genes that likely form A-type channels in vivo: $\mathrm{Kv1.4}$, a putative presynaptic $\mathrm{K}^{+}$channel subunit involved in control of neurotransmitter release, and $\mathrm{Kv} 4.2$, a dendritic $\mathrm{K}^{+}$channel subunit potentially important in regulating postsynaptic excitability (Sheng ct al., 1992).

$\mathrm{Kvl}$.2, like Kv1.4, is a member of the Shaker subfamily of voltage-gated $\mathrm{K}^{+}$channels (Stühmer et al., 1989; Jan and Jan, 1990; Roberds and Tamkun, 1991). In contrast to Kvl.4, Kv1.2 encodes a very slowly inactivating "delayed rectifier"-type $\mathrm{K}^{+}$ conductance when expressed as a homomultimer in Xenopus oocytes (Stühmer et al., 1989). With respect to pharmacological properties, Kv1.2 channels exhibit a particularly high sensitivity to 4-aminopyridine (4AP) and dendrotoxin (DTX) (Stühmer et al., 1989), and, indeed, Kv1.2 subunits have been shown biochemically to be the major component of the DTX acceptor protein(s), purified from brain by DTX affinity chromatography (Scott et al., 1990). In a combined in situ hybridization (ISH) and immunocytochemical analysis, we report here that the subcellular distribution of the Kv1.2 subunit varies in different neuronal cell types in rat brain. In some neurons expressing the $\mathrm{Kv} 1.2$ gene, the Kv1.2 protein appears predominantly in nerve terminals, while in others it is found mainly in dendrites. Based on the fact that Kv1.2 forms heteromultimers with several other $\mathrm{K}^{+}$channel subunits, we speculate that its differential subcellular distribution could be the result of passive targeting of $\mathrm{Kv} 1.2$, directed by distinct subunit partners in different neurons. In this way, Kv1.2 could participate in different heteromultimers and play diverse functional roles in different neurons in the nervous system. 


\section{Materials and Methods}

Antibody production. $\mathrm{Kv} 1.2 \mathrm{C}$ antibodies were raised in rabbits against the peptide CNEDFREENLKTANCTLANT [corresponding to residues $468-486$, near the C-terminus of the predicted Kv1.2 gene product (Stühmer et al., 1989)] as described (Sheng et al., 1992). Antibodies were then affinity purified by standard methods (Harlow and Lane, 1988) on an antigen column, which was made by coupling the antigenic peptide via its cysteine residue to Sulfolink columns (Pierce, Rockford, IL).

Immunoblot. Brain membranes were prepared as described (Sheng et al., 1992) in the presence of phenylmethylsulfonyl fluoride (1 mM), aprotinin $(2 \mu \mathrm{g} / \mathrm{ml})$, benzamidine $(1 \mathrm{mM})$, leupeptin $(1 \mu \mathrm{g} / \mathrm{ml})$, and pepstatin $(1 \mu \mathrm{g} / \mathrm{ml})$. Western blotting was performed as described (Sheng et al., 1992) using affinity-purified $\mathrm{Kv} 1.2 \mathrm{C}$ antibodies at $1-2 \mu \mathrm{g} / \mathrm{ml}$. Donkey anti-rabbit IgG conjugated with horse radish peroxidase (Amersham, Arlington Heights, IL) was applied at 1:5000 for $1 \mathrm{hr}$ at room temperature, and visualized using enhanced chemiluminescence reagents (ECL, Amersham).

Immunohistochemistry. Immunohistochemistry was performed both on $10 \mu \mathrm{m}$ cryostat sections of fresh-frozen rat brain as described (Sheng et al., 1992), and on free-floating brain sections from rats that had been anesthetized with pentobarbital and perfused with $4 \%$ formaldehyde/ $0.1 \%$ glutaraldehyde via the transcardiac route. Sections $(50 \mu \mathrm{m})$ were cut with a Vibratome, washed in $0.1 \mathrm{M}$ Tris, $\mathrm{pH} 7.6$, and treated with $1 \%$ hydrogen peroxide for $30 \mathrm{~min}$. After further washing in Tris-buffered saline (TBS: $50 \mathrm{~mm}$ Tris, $\mathrm{pH} 7.6,100 \mathrm{~mm} \mathrm{NaCl}$ ), sections were blocked for $30 \mathrm{~min}$ in TBS containing $0.1-0.3 \%$ Triton X-100, plus $3 \%$ normal goat serum, and $0.1 \%$ BSA. Affinity-purified $\mathrm{Kvl} .2 \mathrm{C}$ antibodies were applied in the same medium at $2 \mu \mathrm{g} / \mathrm{ml}$, overnight. Biotinylated goat anti-rabbit secondary antibodies and avidin-biotin HRP complexes (Vectastain Elite, Vector Labs, Burlingame, CA) were applied for $2 \mathrm{hr}$ each, with intervening washes $(3 \times 15 \mathrm{~min})$ in TBS containing $0.1 \%$ Triton. Antigen was visualized by incubation in diaminobenzidine $(0.5$ $\mathrm{mg} / \mathrm{ml}$ ) and hydrogen peroxide $(0.01 \%)$. Overall similar results were obtained with frozen sections or free-floating perfusion-fixed sections, though the cellular architecture was better preserved with the latter method.

In situ hybridization. ISH was performed as described in detail in Tsaur et al. (1992).

\section{Results}

$\mathrm{Kv} 1.2$ mRNA is widely expressed in a distinctive pattern in the rat brain (Tsaur et al., 1992). To determine the distribution of the Kv1.2 protein, we raised antibodies (termed Kv1.2C) against a peptide from the C-terminal part of the polypeptide, a region that is highly divergent in amino acid sequence between known $\mathrm{K}^{+}$channel genes.

\section{Immunoblot analysis of Kv1.2 polypeptides}

On immunoblots of rat brain membranes, affinity-purified $\mathrm{Kvl}$.2C antibodies recognize a diffuse band (consisting of a heterogeneous set of polypeptides) with a relative molecular size of $\sim 75-85 \mathrm{kDa}$, as well as an additional band of $\sim 68 \mathrm{kDa}$ (Fig. 1). The $75-85 \mathrm{kDa}$ bands were abolished by preincubation of the antibodies with excess immunogen peptide, and was not detectable in $\mathrm{GH}_{3}$ cells (Fig. $1 B$ ), a cell line that does not express the Kv1.2 mRNA as measured by Northern analysis or by a sensitive reverse-transcriptase polymerase chain reaction assay (M. Sheng and L. B. Shi, unpublished observations). Interestingly, diffuse immunoblot bands of similar size and heterogeneity have also been detected using antibodies against DTXbinding protein (Rehm et al., 1989; Muniz et al., 1992), which consists predominantly of Kv1.2 (Scott et al., 1990).

The additional band of $\sim 68 \mathrm{kDa}$ is also specifically competed by the Kv1.2C peptide (Fig. $1 B$ ), but this band almost certainly does not represent a product of the Kvl.2 gene because (1) it is present in $\mathrm{GH}_{3}$ cells, (2) it behaves quite differently from the 75-85 kDa polypeptides on anion-exchange chromatography (Sheng et al., 1993), and (3) unlike the 75-85 kDa bands, it does
A
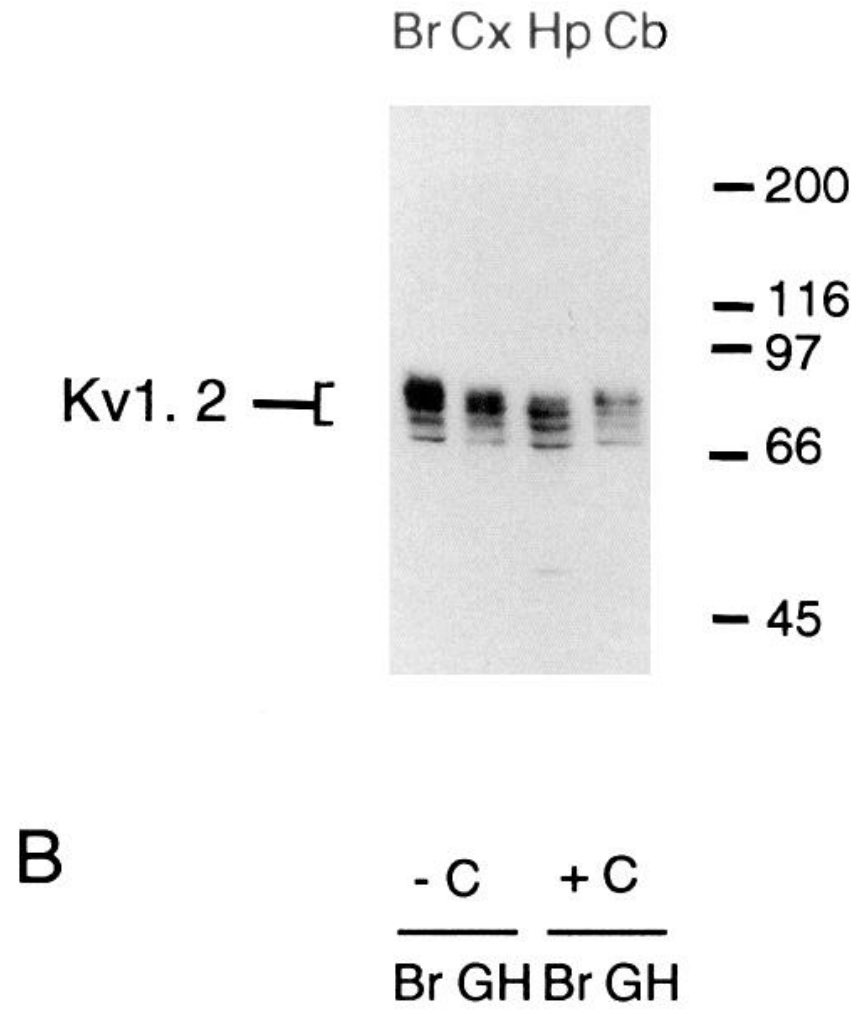

Figure 1. Characterization of Kv1.2 protein by immunoblot. A, Membrane proteins $(\sim 15 \mu \mathrm{g})$ prepared from regions of rat brain were separated by SDS-PAGE and subjected to Western blot analysis. The heterogeneous band(s) of $75-85 \mathrm{kDa}$, which are likely to correspond to Kv1.2 polypeptides, are indicated by a bracket $(K v 1.2)$. An additional band $(\sim 68 \mathrm{kDa}$ ) is also recognized by the $\mathrm{Kv1} .2 \mathrm{C}$ antibodies (see $\mathrm{Re}$ sults). $B r$, whole brain; $C x$, cerebral cortex; $H p$, hippocampus; $C b$, cerebellum. Positions of molecular weight markers are indicated, in $\mathrm{kDa}$. $B$, The $75-85 \mathrm{kDa}$ band recognized by $\mathrm{Kv} 1.2 \mathrm{C}$ antibodies in rat whole brain $(\mathrm{Br})$ is absent in rat $\mathrm{GH}_{3}$ cells $(\mathrm{GH})$, and is abolished by preincubation of $\mathrm{Kv} 1.2 \mathrm{C}$ antibodies with an excess of the $\mathrm{Kv} 1.2 \mathrm{C}$ immunogenic peptide $(+C, 10 \mu \mathrm{g} / \mathrm{ml} \mathrm{Kv1.2C} \mathrm{peptide;}-C$, no competitor peptide). The additional band of $\sim 68 \mathrm{kDa}$, which is present in $\mathrm{GH}_{3}$ cells and in the brain, is also specifically competed by excess $\mathrm{Kv1.2 \textrm {C }}$ peptide, but it almost certainly represents an unrelated polypeptide (see Results). The immunoblot in $B$ was exposed longer than that in $A$ in order to show absence of specific signal in $\mathrm{GH}_{3}$ cells and in competition controls; thus, the Kv1.2 band(s) is seen as more diffuse.

not copurify or coimmunoprecipitate with the related $\mathrm{K}^{+}$channel subunit $\mathrm{Kv} 1.4$, and is not immunoprecipitated by $\mathrm{Kv} 1.2 \mathrm{C}$ antibodies (Sheng et al., 1993).

Taken together, these results suggest that the $75-85 \mathrm{kDa}$ poly- 

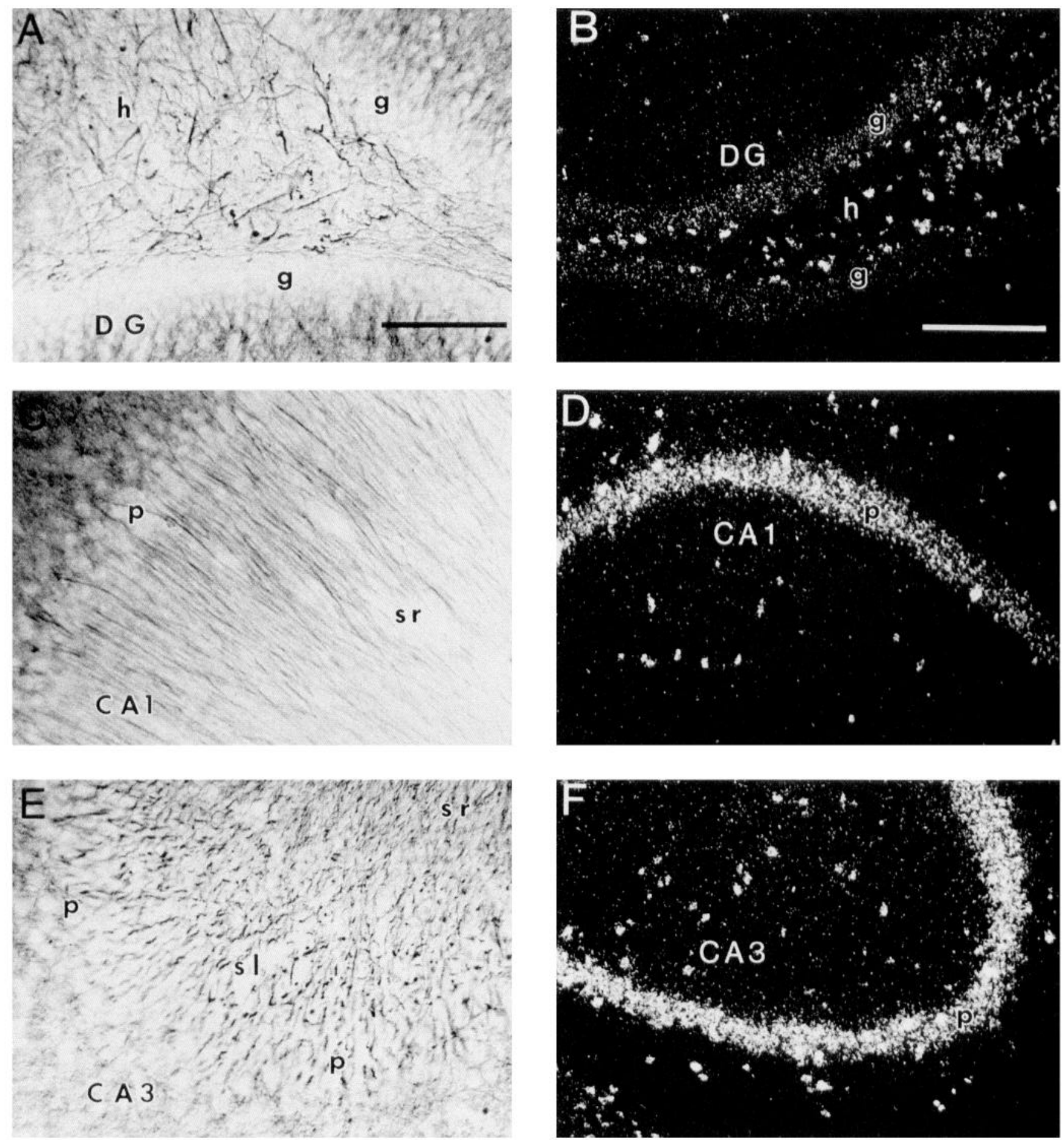

Figure 2. Kv1.2 immunoreactivity in dendrites of pyramidal and hilar neurons in hippocampus: staining pattern of affinity-purified Kv1.2C antibodies in dentate gyrus region $(A)$, CA1 region $(C)$, and CA3 region $(E)$ of the hippocampus. ISH patterns (dark-field illumination) of Kvl.2 mRNA are shown for the same regions in $B, D$, and $F$, respectively. $D G$, dentate gyrus; $g$, granule cell layer of dentate gyrus; $h$, hilus of dentate gyrus; $p$, pyramidal cell layer; $s r$, stratum radiatum; $s l$, stratum lucidum. Scale bars: $A, C$, and $E, 0.16 \mathrm{~mm} ; B, D$, and $F, 0.4 \mathrm{~mm}$.

peptides recognized by $\mathrm{Kv} 1.2 \mathrm{C}$ antibodies represent the products of the $\mathrm{Kv} 1.2$ gene, and that the $68 \mathrm{kDa}$ band is a protein that cross-reacts to the $\mathrm{Kv} 1.2 \mathrm{C}$ antibodies. This conclusion is further supported by developmental correlations with Kv1.2 mRNA expression (see Discussion). The $75-85 \mathrm{kDa}$ proteins are present at roughly similar levels in cerebral cortex, hippocampus, and cerebellum (Fig. $1 \mathrm{~A}$ ), in agreement with ISH (Tsaur et al., 1992) and Northern data (Beckh and Pongs, 1990), which reveal abundant expression of Kv1.2 mRNA in all major brain regions.

Immunohistochemical localization of Kv1.2 in rat brain

Immunohistochemical staining with affinity-purified $\mathrm{Kv} 1.2 \mathrm{C}$ antibodies reveals widespread expression of the $\mathrm{Kv} 1.2$ protein 
in rat forebrain and cerebellum, with immunoreactivity detected in both white matter and gray matter. The staining pattern was specific to $\mathrm{Kv} 1.2 \mathrm{C}$ antiserum and was abolished by competition with the immunogenic, but not an unrelated, peptide (data not shown). The subcellular localization of $\mathrm{Kv} 1.2$ is considered below in different parts of the brain.

\section{Hippocampus}

By ISH, Kv1.2 mRNA is concentrated in the cell body layers of the hippocampal formation, with high levels found in the pyramidal cells $(\mathrm{CA} 3>\mathrm{CA} 1)$, and lower levels in the granule cells of the dentate gyrus (Fig. $2 B, D, F$ ). In addition, numerous cells within the hilus of the dentate gyrus express Kv1.2 mRNA abundantly (Fig. $2 B$ ). Parallel immunostaining of hippocampal sections with $\mathrm{Kv} 1.2 \mathrm{C}$ antibodies reveals that $\mathrm{Kv} 1.2$ protein is predominantly associated with the dendrites of pyramidal and hilar neurons (Fig. 2A,C,E). Significantly, the degree of immunoreactivity in the various subregions of the hippocampus correlates with Kv1.2 mRNA distribution, suggesting that the authentic Kv1.2 polypeptide is being detected by $\mathrm{Kv} 1.2 \mathrm{C}$ antibodies. Thus, the dendrites of hilar neurons and of CA3 pyramidal cells are especially heavily labeled, CAl pyramidal cell dendrites are labeled to a lesser degree, and dentate granule cells show little dendritic immunoreactivity (Fig. 2).

The dendritic staining of pyramidal and hilar cells appears to be uniform rather than punctate, and immunoreactivity in pyramidal cell dendrites extends out into fine branches in the stratum radiatum and stratum lacunosum moleculare. The cell bodies of pyramidal neurons, however, show a conspicuous lack of immunoreactivity. Similarly, although occasional hilar neuron somata are faintly outlined, the level of staining in cell bodies is much weaker than in the dendrites of the same hilar cells (Fig. $2 A$ ). We have been unable to detect $\mathrm{Kv} 1.2 \mathrm{C}$ immunoreactivity associated with axons or terminals of pyramidal neurons, although their trajectories and terminal fields are well described in the hippocampus; relatively low levels of $\mathrm{Kv} 1.2$ protein at these locations, however, cannot be excluded. These results suggest that Kv1.2 protein (which is presumably translated in the cell body where its mRNA is localized) is concentrated in the dendritic compartment of hippocampal pyramidal and hilar neurons.

In contrast to hilar and pyramidal neurons, no convincing staining of dentate granule cell dendrites was found. Instead, Kv1.2 immunoreactivity was detected as numerous large puncta along the course of the mossy fiber tract close to the CA3 pyramidal cell layer, in structures characteristic of giant mossy fiber nerve terminals (Fig. $3 A, B$ ). These terminals correspond to en passant synapses made by the axons of dentate granule cell axons (mossy fibers) with the proximal dendrites of CA3 pyramidal cells. No immunoreactivity was detected in the mossy fiber axons, however, in contrast to Kv1.4 (Sheng et al., 1992). Thus, in dentate granule cells, which express relatively low levels of Kv1.2 mRNA (Fig. $2 B$ ), Kv1.2 protein appears to be concentrated in nerve endings.

In addition to the dendritic staining in $\mathrm{CA} 1, \mathrm{CA} 3$, and the hilus, a well-defined band of Kv1.2 immunoreactivity is also present, occupying the middle third of the molecular layer of the dentate gyrus and the stratum lacunosum moleculare of CA1 (Fig. $3 C$ ). These features of the Kv1.2 staining pattern are superimposable with that of $\mathrm{Kv1} .4$, a probable presynaptic $\mathrm{K}^{+}$ channel subunit (Sheng et al., 1992) with which Kv1.2 forms heteromeric channels in vivo (Sheng et al., 1993). The middle third of the dentate molecular layer and the stratum lacunosum moleculare receive the terminations of the medial perforant pathway projection that originates predominantly from layer II ncurons of the medial cntorhinal cortex (Steward and Scoville, 1976), while the outer third of the molecular layer is the terminal field of the lateral perforant path originating from the lateral entorhinal cortex. Interestingly, the neurons of layer II of the medial, but not the lateral, entorhinal cortex express high levels of Kv1.2 mRNA (Fig. $3 D$ ). Taken together, these findings suggest that the band of $\mathrm{Kv} 1.2 \mathrm{C}$ immunoreactivity in the dentate molecular layer is due to the presence of $\mathrm{Kv} 1.2$ subunits in the terminals of the medial perforant path axons.

\section{Cerebellum}

The selective localization of Kv1.2 in nerve terminals is perhaps most convincingly demonstrated in the cerebellum. The most intense $\mathrm{Kvl} 1.2$ immunoreactivity of the whole brain is found here, in the plexuses of nerve terminals that ensheathe the base and initial axon segments of Purkinje cells (Fig. $4 A, B$ ). These plexuses [termed "pinceaus" by Palay and Chan-Palay (1974)] are physically distinguishable from the Purkinje neuron and are uniquely characteristic of the nerve endings of basket cells. Consistent with this interpretation, ISH shows that Kv1.2 mRNA is abundantly expressed in numerous cell bodies in the deep half of the molecular layer of the cerebellar cortex, a distribution characteristic of basket cell somata (Palay and Chan-Palay, 1974). No Kv1.2 immunoreactivity could be detected in the cell bodies and major dendrites of basket cells, even after prolonged immunohistochemical development. Thus, in cerebellar basket cells, the Kv1.2 protein is predominantly, if not exclusively, localized to the nerve terminals. The high concentration of Kv1.2 protein in a restricted compartment of a cell expressing large amounts of the mRNA could account for the extraordinary intensity of immunostaining in basket cell nerve terminals relative to that found in dendrites of hippocampal pyramidal cells and cerebellar Purkinje cells (see below).

ISH reveals that Purkinje cells also express Kv1.2 mRNA (Fig. 4C,D). In contrast to basket cells, however, Purkinje cells show Kvl.2 immunoreactivity in their cell bodies and major dendritic branches, although at a lower density than that found in basket cell nerve endings. Purkinje cells appear to be the only neurons of the rat brain that show relatively high levels of $\mathrm{Kv} 1.2$ immunorcactivity in their soma.

The granule cells of the cerebellar cortex express low levels of Kv1.2 mRNA (Fig. 4C,D; Tsaur et al., 1992), and immunostaining of the granule cell layer is also close to background. A low level of diffuse Kv1.2 immunoreactivity exists in the molecular layer of the cerebellum, but the origin of this staining is unclear.

\section{Cerebral cortex}

$\mathrm{Kv} 1.2 \mathrm{C}$ antibodies stain the neuropil in all regions, and throughout the thickness, of the cerebral cortex. In addition to the general neuropil staining, a striking feature is the labeling of the major apical dendrites of pyramidal neurons: Kvl.2 immunoreactivity appears to be present throughout the length of the apical dendrite and in its terminal branches in layer I (Fig. 5, right). Although Kvl.2 staining is not restricted to particular cortical layers, the most immunoreactive apical dendrites appear to arise in particular from cells in the deeper part of the cortex (layer V). This distribution correlates with ISH, which reveals Kvl.2 hybridization throughout the cortex, with partic- 

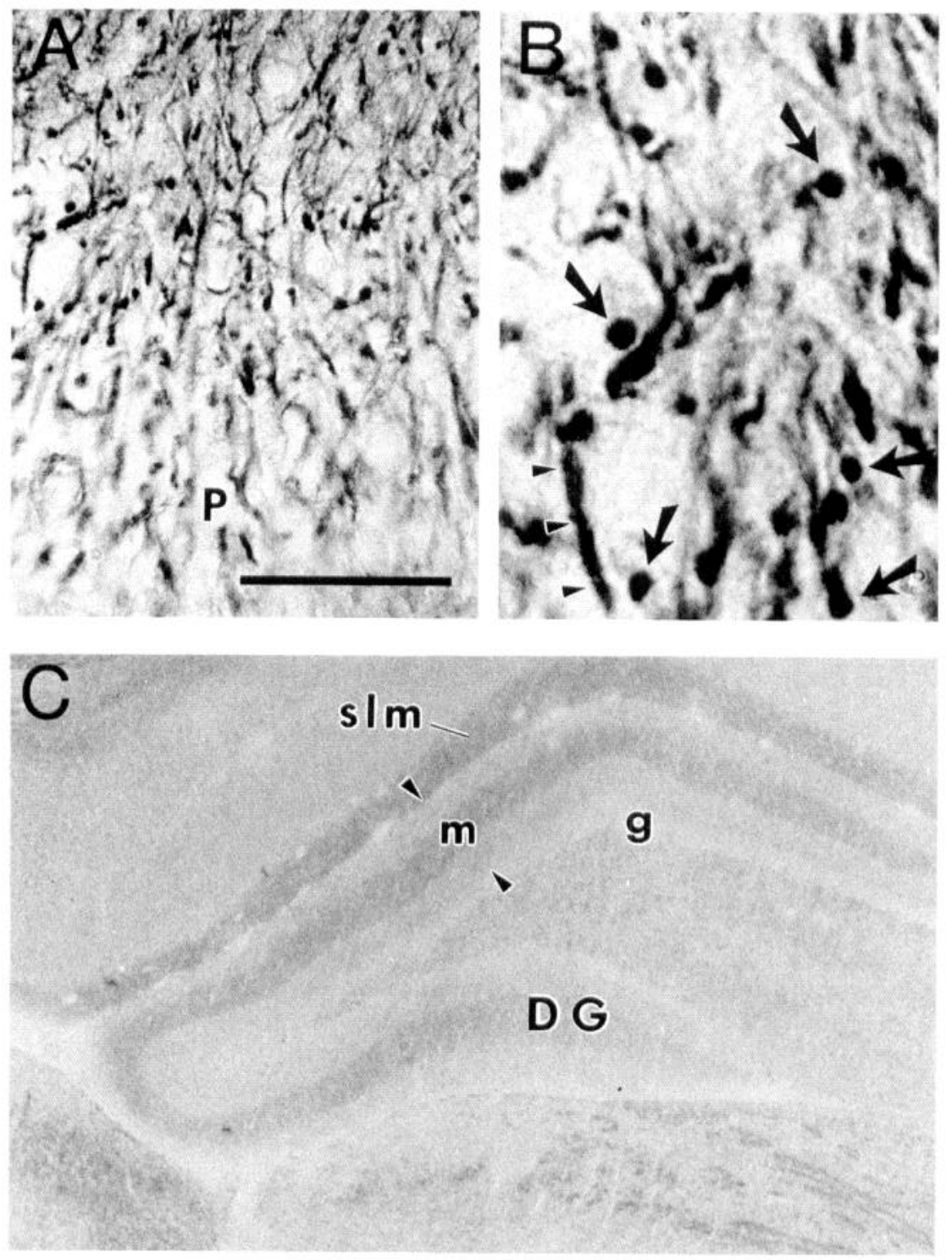

Figure 3. Kv1.2 immunoreactivity in nerve terminals of the mossy fiber tract and in the terminal field of the media perforant path projection. $A$ and $B$, $\mathrm{Kv} 1.2$ is present in numerous large puncta (arrows), which lie along the course of the mossy fiber axon tract closely associated with the proximal apical dendrites of $\mathrm{CA} 3$ pyramidal cells ( $B$ is a higher-magnification view of $A$ ). Pyramidal cell dendrites are also stained by $\mathrm{Kv} 1.2 \mathrm{C}$ antibodies (example outlined by arrows; see also Fig. $2 E$ ). $C, \mathrm{~A}$ relatively dense band of Kv1.2 immunoreactivity is present in the middle third of the molecular layer of the dentate gyrus $(m$; the full thickness of the molecular layer is demarcated with arrowheads), and in the stratum lacunosum moleculare $(\mathrm{slm})$ of CA1. D, ISH of the entorhinal cortex, showing Kv1.2 mRNA expression concentrated in layer II of the medial entorhinal cortex $(M E C)$, but not in lateral entorhinal cortex $(L E C)$. Other abbreviations are as in Figure 2. Scale bar: $A, 125 \mu \mathrm{m} ; B$, $50 \mu \mathrm{m} ; C$ and $D, 1.0 \mathrm{~mm}$.

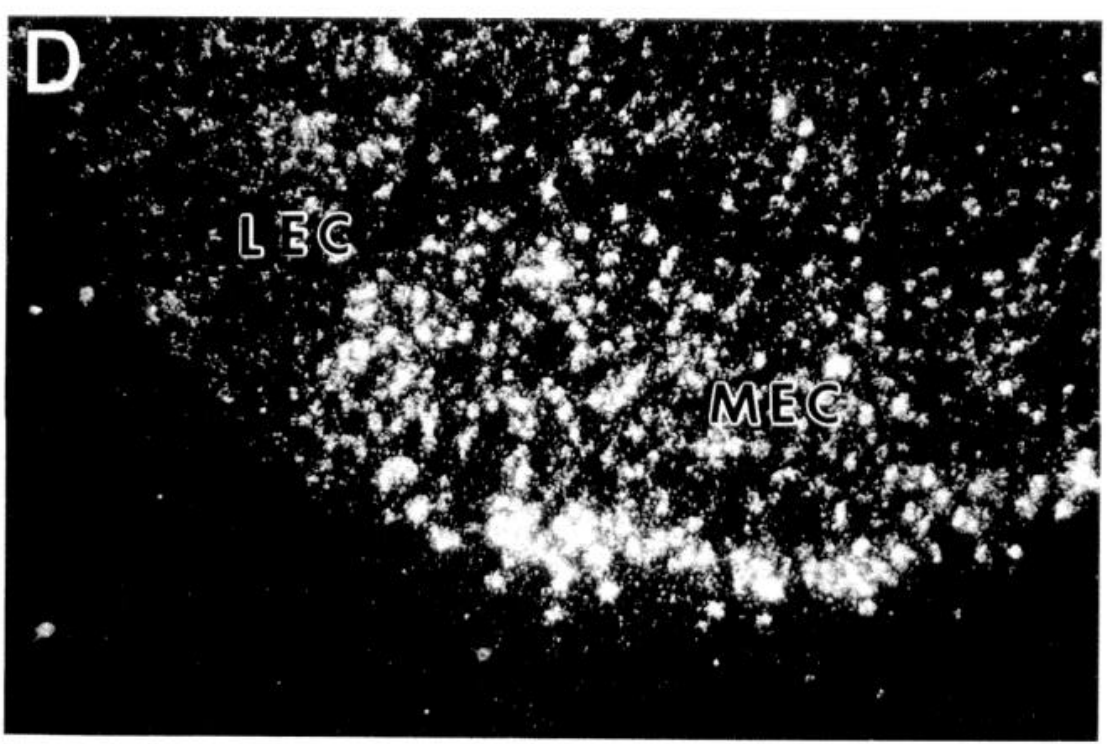



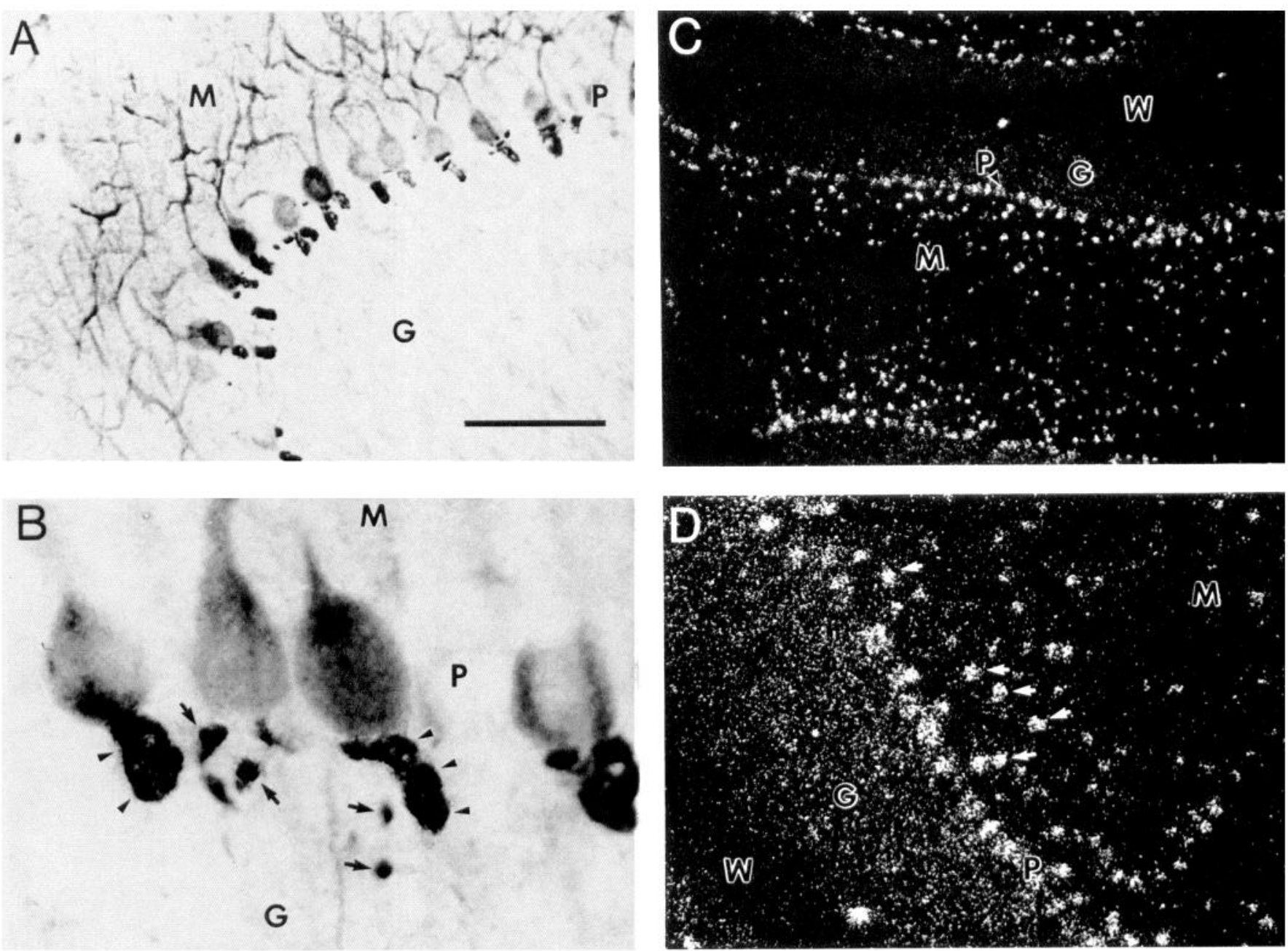

Figure 4. $\mathrm{Kv} 1.2$ in the cerebellar cortex. $A, \mathrm{Kv} 1.2$ immunoreactivity is particularly prominent in the nerve terminal plexuses of basket cells, as well as being present in Purkinje cell somata $(P)$ and major dendrites. Diffuse Kv1.2 staining is present at a low level in the molecular layer $(M)$, but appears absent from the granule cell layer $(G) . B$. Higher-magnification view of Purkinje cell layer $(P)$ showing staining of the basket cell nerve terminal plexuses, or pinceaus (arrowheads), which are wrapped around the base and initial axon segments of the Purkinje neurons. Arrows indicate smaller clusters of basket cell endings, some of which are out of the focal plane. $C$ and $D$, ISH pattern of Kv1.2 mRNA in cerebellar cortex. $G$, granule cell layer; $M$, molecular layer; $P$, Purkinje cell layer; $W$, white matter. Arrows indicate Kv1.2 hybridization signals overlying cell bodies in the deep part of the molecular layer; these have the typical distribution of basket cell somata. Scale bar: $A, 0.16 \mathrm{~mm} ; B, 40 \mu \mathrm{m} ; C, 0.4 \mathrm{~mm} ; D$, $0.2 \mathrm{~mm}$.

ularly dense signal over large cell bodies in layer V (Fig. 5, left). In contrast to mRNA localization, the somata of pyramidal cells (and other cortical neurons) are relatively spared of Kv1.2 immunoreactivity and appear as "white holes" against the general neuropil staining (Fig. 5, right).

\section{White matter}

$\mathrm{Kv1.2}$ immunoreactivity is present in the corpus callosum, the large white matter tract connecting the two cerebral hemispheres (Fig. 6A). The staining appears as numerous fibers running horizontally through the corpus callosum, though the degree of staining is not homogeneous, being more intense in the ventral portion of the corpus callosum. No immunoreactivity was found to be associated with glial cells in the corpus callosum; this is consistent with ISH, which shows an absence of cells expressing Kv1.2 mRNA in white matter tracts (Fig. $6 B$ ). In conjunction with $\mathrm{Kv} 1.2$ staining in the white matter of the internal capsule (data not shown), these findings suggest that the $\mathrm{Kv} 1.2 \mathrm{~K}^{+}$channel subunit is present in axons of projection neurons.

\section{Discussion}

\section{Heterogeneity of Kv1.2 polypeptides}

Although partial proteolysis cannot be totally excluded, we think that the heterogeneity of the Kv1.2 (75-85 kDa) bands detected on immunoblot is unlikely to be due to protein degradation because (1) the heterogeneity was reproducible in different membrane preparations from different rats, (2) protease inhibitors were present throughout membrane preparation, which was always performed at $<4^{\circ} \mathrm{C}$, and (3) the same membrane protein preparations, or even the same immunoblot, showed no evidence of proteolysis when probed with antibodies against other $\mathrm{K}^{+}$channel or glutamate receptor subunits.

The difference in size from the predicted molecular weight of $\mathrm{Kv} 1.2(57 \mathrm{kDa})$ could be explained at least in part by posttranslational modifications such as glycosylation, which is predicted from the sequence of the protein (Stühmer et al., 1989; Roberds and Tamkun, 1991), and suggested by the strong binding of Kv1.2 polypeptides to lectin columns (Sheng et al., 1993). Our 

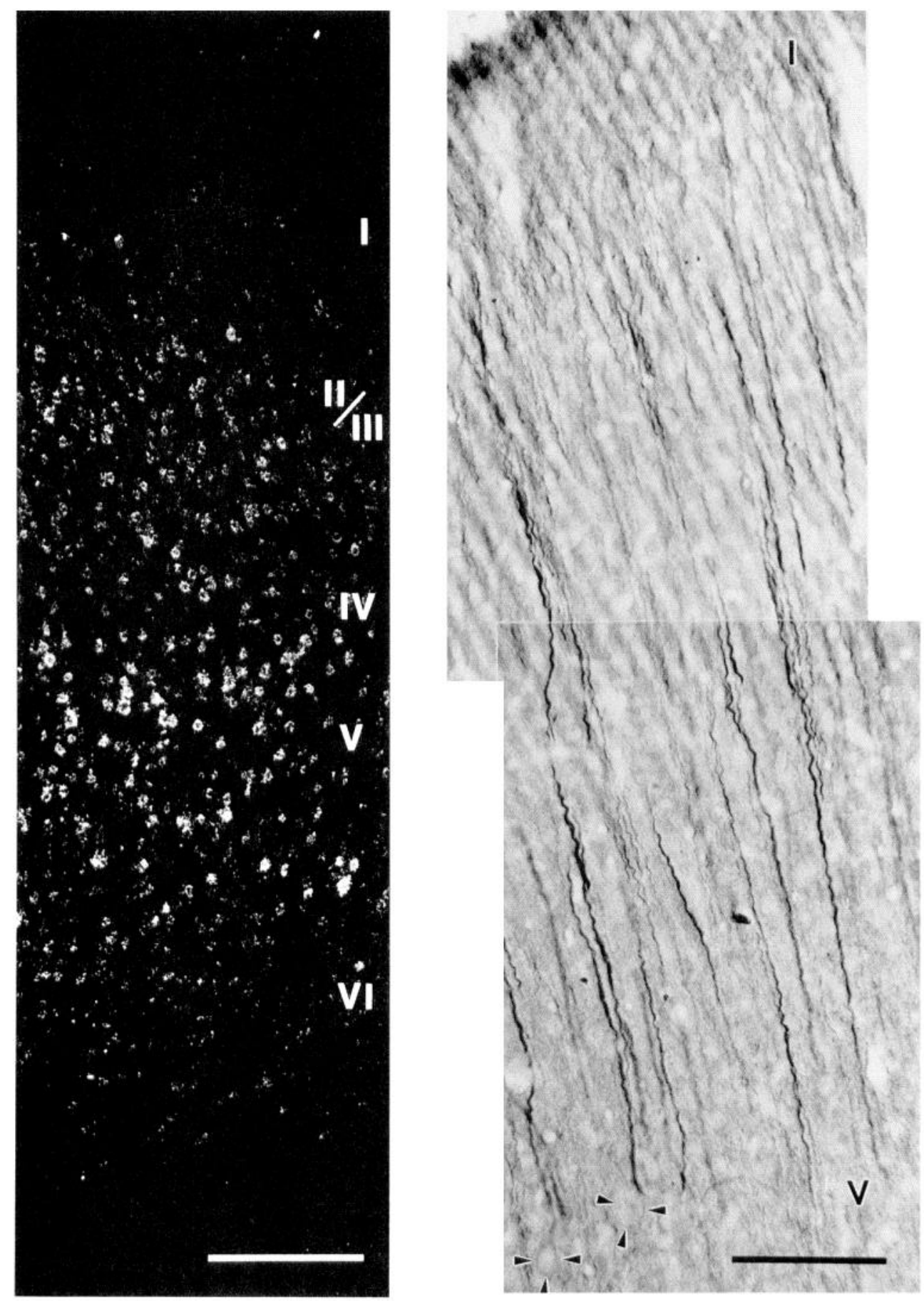

Figure 5. Kv1.2 in cerebral cortex. Left, Kv1.2 ISH pattern. Right, Kv1.2 immunostaining pattern. Kv1.2 mRNA is expressed throughout the thickness of the cortex, but particularly strongly in large cells of layer V. Kv1.2 immunoreactivity is found throughout the cortex, and prominently in the major apical dendrites of pyramidal neurons. Cell bodies are relatively spared of Kv1.2 staining and can be seen as white holes against the general neuropil staining. Arrowheads indicate occasional cell bodies that are faintly outlined, giving rise to the densely immunoreactive apical dendrites. Approximate positions of the cortical layer are indicated. Scale bars: left, $0.4 \mathrm{~mm}$; right, $0.16 \mathrm{~mm}$.

findings are consistent with recent studies showing that Kv1.2/ DTX-binding protein is composed of immunologically related glycoproteins of similar size and heterogeneity (Rehm et al., 1989; Muniz et al., 1992). The reason for the heterogeneity of $\mathrm{Kv} 1.2$ polypeptides is unknown, but it is tempting to speculate that it may be related to the differential subcellular distributions of Kv1.2 protein. The heterogeneity cannot be accounted for solely by differential glycosylation, however, since deglycosylation reduces the molecular size, but has little effect on the degree of heterogeneity, of Kv1.2/DTX-acceptor proteins (Rehm et al., 1989; Muniz et al., 1992).

\section{Localization of Kv1.2 proteins}

Peptide antibodies directed against the C-terminal region of $\mathrm{Kv} 1.2$ have been used to localize this $\mathrm{K}^{+}$channel subunit in sections of rat brain. Taken together, the immunoblot analysis, the competition controls, and the correlation between immunohistochemical and ISH findings, argue in favor of the specificity of $\mathrm{Kv} 1.2 \mathrm{C}$ antibodies, and suggest that the immunostaining pattern correctly reflects the localization of the Kv1.2 protein. This conclusion is supported by the fact that the degree of $\mathrm{Kv} 1.2 \mathrm{C}$ immunohistochemical staining increases during postnatal de- 

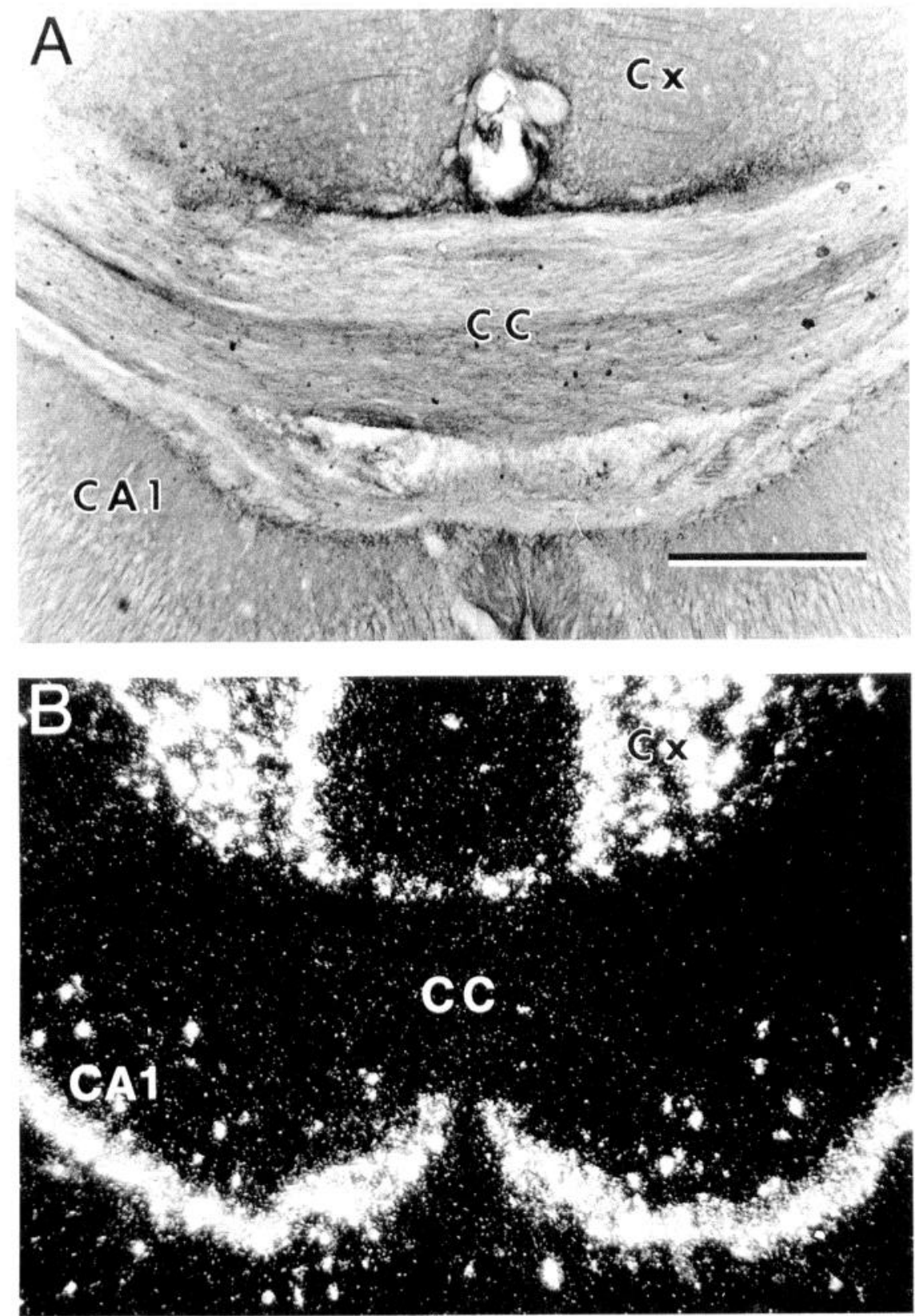

Figure 6. Kv1.2 in the corpus callosum. $A, \mathrm{Kv} 1.2$ immunostaining in the white matter of the corpus callosum $(C C)$ is denser in the ventral half. $B$, ISH reveals that no cells within the corpus callosum express the Kv1.2 mRNA. $C x$, retrosplenial cortex. Scale bar, 0.6 $\mathrm{mm}$. velopment, correlating with rising levels of the $75-85 \mathrm{kDa}$ polypeptides (M. Sheng and L. A. Roldan, unpublished observations), and with the increasing expression of Kv1.2 mRNA (Beckh and Pongs, 1990). In contrast, the $68 \mathrm{kDa}$ band is present at similarly abundant levels from birth to adult. These developmental correlations suggest that $\mathrm{Kv1} .2 \mathrm{C}$ is recognizing the $75-$ $85 \mathrm{kDa}$ rather than the $68 \mathrm{kDa}$ protein(s) in brain sections, and further support the idea that the $75-85 \mathrm{kDa}$ bands represent products of the Kv1.2 gene.

In addition, the overall pattern of $\mathrm{Kv} 1.2 \mathrm{C}$ antibody staining is similar to the pattern of DTX radioligand binding observed in rat brain sections (Pelchen-Matthews and Dolly, 1989; Awan and Dolly, 1991). Since Kv1.2 subunits represent the predominant component of DTX-binding proteins in the brain (Scott et al., 1990), this agreement lends independent support to appropriate recognition by our Kv1.2C antibodies. Nevertheless, given the heterogeneity of $\mathrm{Kv} 1.2(75-85 \mathrm{kDa})$ polypeptides on immunoblots, it should be borne in mind that the $\mathrm{Kv} 1.2 \mathrm{C}$ antibodies may be recognizing a set of very highly related, but nonidentical, proteins in tissue sections.

$\mathrm{Kv} 1.2$ protein is widely expressed across the different regions of the rat brain, and like DTX-binding sites, is found in both white matter and synapse-rich areas (Pelchen-Matthews and Dolly, 1989; Awan and Dolly, 1991). We have not examined in detail for expression in glial cells, but our results indicate that $\mathrm{Kv} 1.2$ is found predominantly in neurons.

At the subcellular level, the relative distribution of Kv1.2 protein between dendrites, axons, and nerve terminals is surprisingly variable in different neurons. With the exception of Purkinje cells, Kv1.2 immunoreactivity is relatively absent from neuronal cell bodies, where its mRNA is localized. The subcellular distribution of $\mathrm{Kv} 1.2$ subunits is thus complex, con- 
trasting with the stereotypical segregation of $\mathrm{Kv1} .4$ and $\mathrm{Kv} 4.2$ subunits to axonal/terminal and somatodendritic compartments, respectively (Sheng et al., 1992).

\section{Differential subcellular localization of Kv1.2 in different cell types}

Although Kvl.2 is found in many subcellular compartments when the whole brain is considered, this reffects a summation of individual neuronal types in which Kv1.2 appears to be differentially distributed among distinct domains. Thus, in pyramidal neurons of the hippocampus and cortex $\mathrm{Kv} 1.2$ protein is found in dendrites, whereas in cerebellar basket cells and dentate granule cells $\mathrm{Kv} 1.2$ appears to be predominantly, if not exclusively, localized to the axon terminals. As an example of another class, Purkinje cells express $\mathrm{Kv} 1.2$ in their somata as well as in major dendrites. For hippocampal pyramidal neurons and cerebellar Purkinje cells (both of which have well-described projections and terminal fields), we could not detect any immunoreactivity, suggesting Kv1.2 localization in axons or nerve terminals, although low levels could not be excluded. These results demonstrate that certain defined cell types in rat brain differ in their subcellular distribution of Kv1.2 protein. How might this arise?

One-possibility is that targeting signals in the Kv1.2 protein are recognized differently in different neurons, resulting in sorting to distinct subcellular locations. Alternatively, $\mathrm{Kv} 1.2$ is differentially modified in a cell type-specific manner, thus altering the specificity of a targeting determinant. Another possibility is that differential extracellular interactions (e.g., with matrix components or proteins on the surfaces of neighboring cells) could determine Kv1.2 subcellular localization. The hypothesis that we favor, however, is that the Kv1.2 subunit contains no (or only weak) intrinsic sorting signals, but homes passively to various subcellular domains by virtue of its association with another $\mathrm{K}^{+}$channel subunit that is segregated in "active" fashion. The direction of Kv1.2 sorting would then be determined by the balance of "dominant partner" subunits coexpressed with $\mathrm{Kv} 1.2$ in a particular neuron. Consistent with this idea is the finding that $\mathrm{Kv1} 1.2$ protein is complexed with several other $\mathrm{K}^{+}$ channel subunits in rat brain, including Kvl.4 (Sheng et al., 1993), Kv1.1 (Wang et al., 1993), and Kv1.3 (M. Sheng, unpublished observations). Moreover, all of these genes show pronounced cell type-specific differences in expression, typical of $\mathrm{K}^{+}$channel subunit genes in general (Baldwin et al., 1991; Drewe et al., 1992; Hwang et al., 1992; Rettig et al., 1992; Sheng et al., 1992; Tsaur et al., 1992), thereby allowing for differential heteromultimerization and targeting. Recently, the direction of sorting of the GABA receptor $\alpha 1$ subunit in transfected polarized epithelia was shown to change after assembly with the $\beta 1$ subunit (Perez-Velasquez and Angelides, 1993), providing an in vitro precedent for a "passive follower" routing mechanism.

One subunit that is directly complexed with $\mathrm{Kv} 1.2$ in rat brain membranes is Kv1.4 (Sheng et al., 1993), a $\mathrm{K}^{+}$channel polypeptide that is segregated to the axonal/nerve terminal compartment of expressing neurons (Sheng et al., 1992). The localization of Kv1.2 to the terminals of the medial perforant path projection and to the terminals of the mossy fiber axons could be dictated by association with the Kv1.4 protein, since Kvl.4 and $\mathrm{Kv} 1.2$ subunits are coexpressed in the cells of origin of these axons. Varying subunit associations in different kinds of neurons could, thus, account for the complex and diverse subcellular targeting of Kv1.2. An implication of this idea is that the com- position of Kvl.2-containing channels would differ in different subcellular domains.

\section{Functional implications of Kv1.2 localization}

The differential subcellular distribution of Kv1.2 implies that this $\mathrm{K}^{+}$channel subunit performs varying sets of functions in different neurons. One major subcellular location of Kv1.2 appears to be dendritic, as illustrated by hippocampal and cortical pyramidal cells. $\mathrm{Kv} 1.2$-containing $\mathrm{K}^{+}$channels could therefore be involved in the regulation of postsynaptic excitability and integration of synaptic signals in the dendrites of these cells. In this respect, it is noteworthy that somatodendritic DTX-sensitive $\mathrm{K}^{+}$conductances have been recorded in hippocampal pyramidal neurons (Halliwell et al., 1986).

$\mathrm{Kv} 1.2$ is also found in the nerve terminals of certain cell types (e.g., basket cells, dentate granule cells, and probably medial perforant path projection neurons). Nerve terminals have a high density of voltage-gated $\mathrm{K}^{+}$channels (Bartschat and Blaustein, 1985; Bielefeldt et al., 1992), and in this location, Kv1.2 would be well placed to regulate the duration of the presynaptic action potential and thus the amount of neurotransmitter release.

The finding of Kv1.2 in white matter tracts of brain is consistent with radioligand studies that reveal numerous DTXbinding sites in white matter areas of rat brain, including the corpus callosum (Halliwell et al., 1986; Pelchen-Matthews and Dolly, 1989; Awan and Dolly, 1991). That Kv1.2 may be complexed with other $\mathrm{K}^{+}$channel subunits that dominantly confer inactivation on the heteromeric channel cannot be excluded (e.g., Kv1.4; Sheng et al., 1993). Nevertheless, the results suggest that Kv1.2 channels, in the form of homomultimers or heteromultimers with other noninactivating subunits, may contribute to delayed rectifier-type $\mathrm{K}^{+}$currents in axons. Slowly inactivating voltage-dependent $\mathrm{K}^{+}$conductances have been described in myelinated axons (Dubois, 1983) and are central to the squid giant axon model of action potential repolarization.

Of the known Shaker-like K+ channels, Kv1.2 is particularly sensitive to 4AP and DTX (Stühmer et al., 1989). Although these pharmacological features are not necessarily unique to $\mathrm{Kv} 1$.2-containing $\mathrm{K}^{+}$channels in vivo, it is, nevertheless, worth noting that DTX-sensitive and 4AP-sensitive $\mathrm{K}^{+}$currents have been described that are consistent with immunolocalization of $\mathrm{Kv} 1.2$ reported here, for example, in the somatodendritic domain of hippocampal pyramidal neurons (Halliwell et al., 1986), in nerve terminals (Anderson and Harvey, 1988; Dolly, 1988; Tibbs et al., 1989; Bielefeldt et al., 1992), and in myelinated nerve fibers (Dubois, 1983; Benoit and Dubois, 1986). Participation of Kv1.2 in these channels could account for their similar pharmacology, while the differences in kinetic behavior of these conductances could be explained by Kv1.2 coassembly with different $\mathrm{K}^{+}$channel subunits in these various locations. The future challenge will be to determine the different molecular compositions and electrophysiological characteristics of the various $\mathrm{Kv} 1.2$-containing $\mathrm{K}^{+}$channels in vivo, and to relate these differences to their specialized functions in neurons.

\section{References}

Anderson AJ, Harvey $\mathrm{AL}$ (1988) Effects of the potassium channel blocking dendrotoxins on acetylcholine release and motor nerve terminal activity. Br J Pharmacol 93:215-221.

Awan KA, Dolly JO (1991) $\mathrm{K}^{+}$channel sub-types in rat brain: characteristic locations revealed using $\beta$-bungarotoxin, $\alpha$ - and $\delta$-dendrotoxins. Neuroscience 40:29-39.

Baldwin TJ, Tsaur M-L, Lopez GA, Jan YN, Jan LY (1991) Char- 
acterization of a mammalian cDNA for an inactivating voltage-sensitive $\mathrm{K}^{+}$channel. Neuron 7:471-483.

Bartschat DK, Blaustein MP (1985) Potassium channels in isolated presynaptic nerve terminals from rat brain. J Physiol (Lond) 361: $419-440$.

Beckh S, Pongs O (1990) Members of the RCK potassium channel family are differentially expressed in the rat nervous system. FMBO J 9:777-782.

Benoit E, Dubois J-M (1986) Toxin I from the snake Dendroaspis polylepis: a highly specific blocker of one type of potassium channel in myelinated nerve fiber. Brain Res 377:374-377.

Bielefeldt K, Rotter JL, Jackson MB (1992) Three potassium channels in rat posterior pituitary nerve terminals. J Physiol (Lond) 458:4167.

Christie MJ, North RA, Osborne PB, Douglass J, Adelman JP (1990) Heteropolymeric potassium channels expressed in Xenopus oocytes from cloned subunits. Neuron 4:405-411.

Dolly JO (1988) Potassium channels - what can the protein chemistry contribute? Trends Neurosci 11:186-188.

Drewe JA, Verma S, Frech G, Joho RH (1992) Distinct spatial and temporal expression patterns of $\mathrm{K}^{+}$channel mRNAs from different subfamilies. J Neurosci 12:538-548.

Dubois JM (1983) Potassium currents in the frog node of Ranvier. Prog Biophys Mol Biol 42:1-20.

Halliwell JV, Othman IB, Pelchen-Matthews A, Dolly JO (1986) Central action of dendrotoxin: selective reduction of a transient $\mathrm{K}^{+}$conductance in hippocampus and binding to localized acceptors. Proc Natl Acad Sci USA 83:493-497.

Harlow E, Lane D (1988) Antibodies: a laboratory manual. Cold Spring Harbor, NY: Cold Spring Harbor Laboratory.

Hille B (1991) Ionic channels of excitable membranes, 2d ed. Sunderland, MA: Sinauer.

Hwang PM, Glatt CE, Bredt DS, Yellen G, Snyder SH (1992) A novel $\mathrm{K}^{+}$channel with unique localizations in mammalian brain: molecular cloning and characterization. Neuron 8:473-481.

Isacoff EY, Jan YN, Jan LY (1990) Evidence for the formation of heteromultimeric potassium channels in Xenopus oocytes. Nature 345:530-534.

Jan LY, Jan YN (1990) How might the diversity of potassium channels be generated? Trends Neurosci 13:415-418.

McCormack JW, Lin LE, Iverson LE, Rudy B (1990) Shaker K+ channel subunits form heteromultimeric channels with novel functional properties. Biochem Biophys Res Commun 171:1361-1371.

Muniz ZM, Parcej DN, Dolly JO (1992) Characterization of monoclonal antibodies against voltage dependent $\mathrm{K}^{+}$channels raised using $\alpha$-dendrotoxin acceptors purified from bovine brain. Biochemistry 31:12297-12303.

Palay SL, Chan-Palay V (1974) Cerebellar cortex: cytology and organization. New York: Springer.

Pelchen-Matthews A, Dolly JO (1989) Distribution in the rat central nervous system of acceptor sub-types for dendrotoxin, a $\mathrm{K}^{+}$channel probe. Neuroscience 29:347-361.
Perez-Velazquez JL, Angelides KJ (1993) Assembly of GABA receptor subunits determines sorting and localization of polarized cells. Nature 361:457-460.

Rehm H, Newitt RA, Tempel BL (1989) Immunological evidence for a relationship between the dendrotoxin-binding protein and the mammalian homologue of the Drosophila Shaker $\mathrm{K}^{+}$channel. FEBS Lett 249:224-228

Rettig J, Wunder F, Stocker M, Lichtinghagen R, Mastiaux F, Beckh S, Kues W, Pedarzani P, Schroter KH, Ruppersberg JP, Veh R, Pongs $O$ (1992) Characterization of a Shaw-related potassium channcl family in rat brain. EMBO J 11:2473-2486.

Roberds SL, Tamkun MM (1991) Cloning and tissue-specific expression of five voltage-gated potassium channel cDNAs expressed in rat heart. Proc Natl Acad Sci USA 88:1798-1802.

Ruppersberg JP, Schroter KH, Sakmann B, Stocker M, Sewing S, Pongs $O$ (1990) Heteromultimeric channels formed by rat brain potassium channel proteins. Nature 345:535-537.

Salkoff L, Baker K, Butler A, Covarrubias M, Pak MD, Wei A (1992) An essential set of $\mathrm{K}^{+}$channels conserved in flies, mice, and humans. Trends Neurosci 15:161-166.

Scott VES, Parcej DN, Keen JN, Findlay JBC, Dolly JO (1990) Dendrotoxin acceptor from bovine brain is a $\mathrm{K}^{+}$channel protein. Evidence from the $\mathrm{N}$-terminal sequence of its larger subunit. J Biol Chem 265:20094-20097.

Sheng M, Tsaur M-L, Jan YN, Jan LY (1992) Subcellular segregation of two A-type $\mathrm{K}^{+}$channel proteins in rat central neurons. Neuron 9:271-284.

Sheng M, Liao YJ, Jan YN, Jan LY (1993) Detection of heteromultimeric $\mathrm{K}^{+}$channels in vivo: potential molecular basis of a presynaptic A-current. Nature 365:72-75.

Steward O, Scoville SA (1976) Cells of origin of entorhinal cortical afferents to the hippocampus and fascia dentata of the rat. J Comp Neurol 169:347-376.

Stühmer W, Ruppersberg JP, Schröter KH, Sakmann B, Stocker M, Giese KP, Perschke A, Baumann A, Pongs O (1989) Molecular basis of functional diversity of voltage gated potassium channels in mammalian brain. EMBO J 8:3235-3244.

Tibbs GR, Dolly JO, Nicholls DG (1989) Dendrotoxin, 4-aminopyridine, and $\beta$-bungarotoxin act at common loci but by two distinct mechanisms to induce calcium-dependent release of glutamate from guinea pig cerebrocortical synaptosomes. J Neurochem 52:201-206.

Tsaur ML, Sheng M, Lowenstein DH, Jan YN, Jan LY (1992) Differential expression of $\mathrm{K}^{+}$channel mRNAs in rat brain and downregulation in the hippocampus following seizures. Neuron 8:10551067.

Wang H, Kunkel DD, Martin TM, Schwartzkroin PA, Tempel BL (1993) Heteromultimeric $\mathrm{K}^{+}$channels in terminal and juxtaparanodal regions of neurons. Nature 365:75-79. 